Studia Anglica Posnaniensia 51/4, 2016

doi: 10.1515/stap-2016-0017

\title{
THE REPRESENTATION OF FRANCOIST SPAIN BY TWO BRITISH WOMEN TRAVEL WRITERS
}

\author{
MAUREEN MULLIGAN* \\ Universidad de Las Palmas de Gran Canaria, Spain
}

\begin{abstract}
This article offers a discussion of two books by British women which describe travels in Spain during the post-war period, that is, during the dictatorship of General Franco. The aim is to analyse how Spanish culture and society are represented in these texts, and to what extent the authors engage with questions of the ethics of travelling to Spain in this period. Two different forms of travel - by car, and by horse - also influence the way the travellers can connect with local people; and the individual's interest in Spain as a historical site, or as a timeless escape from industrial northern Europe, similarly affect the focus of the accounts. The global politics of travel writing, and the distinction between colonial and cosmopolitan travel writers, are important elements in our understanding of the way a foreign culture is articulated for the home market. Women's travel writing also has its own discursive history which we consider briefly. In conclusion, texts involve common discursive and linguistic strategies which have to negotiate the specificity of an individual's travels in a particular time and place. The authors and books referred to are Rose Macaulay's Fabled Shore: From the Pyrenees to Portugal (1949) and Penelope Chetwode's Two Middle-Aged Ladies in Andalusia (1963).
\end{abstract}

Keywords: travel writing, ethics, post-war Spain, tourism, women travellers

\section{Introduction}

This article offers a discussion of two books by British women which describe travels in Spain during the post-war period, that is, during the dictatorship of General Franco from 1939 to 1975 . The authors and books referred to are Rose Macaulay's Fabled Shore: From the Pyrenees to Portugal (1949) and Penelope

Corresponding author: Department of Modern Philology, c. Pérez del Toro 1, 35003 Las Palmas de Gran Canaria, Spain, email: maureen.mulligan@ulpgc.es. 
Chetwode's Two Middle-Aged Ladies in Andalusia (1963). The aim is to analyse how the Spanish culture and society of the time are represented in these texts, and to what extent the authors engage with questions of the ethics of travel to Spain in this period. Two different forms of travel - by car, and by horse - also influence the way the travellers can connect with local people; and the individual's interest in Spain as a historical site, or as a timeless escape from industrial northern Europe, similarly affect the focus of the accounts. The global politics of travel writing, and the distinction between colonial and cosmopolitan travel writers, are important elements in our understanding of the way a foreign culture is articulated for the home market. Women's travel writing also has its own discursive history which we consider briefly. In conclusion, texts involve common discursive and linguistic strategies which have to negotiate the specificity of an individual's travels in a particular time and place.

When we read these texts with the hindsight of a historical perspective, inevitably we ask why these women chose to come to Spain, to what extent they were aware of the political situation in the country and whether they adopted a political or ethical stance towards the society they visited. Similarly, it is important to establish whether they ever felt uneasy about travelling in a country affected by war, poverty, division and dictatorship. There is a hierarchy of mobility implicit in travel writing which most commonly deals with wealthy people travelling from democracies to poorer, often undemocratic societies whose members do not have freedom of movement or resources to travel: this leads us to ask how this inequality of movement is dealt with by the traveller. At the same time, each individual traveller has her own personal agenda, which influences her choice of itinerary, her mode of travel, her interests and blind spots, her aims and priorities. From a literary perspective, we can analyse the way the language and style they use to describe the experience reflect the complex questions that must have arisen in the course of the journey. We ask how people choose to travel to certain countries at certain times, what they know about the place in advance of travelling, how they represent it through their writing, and how readers interpret their texts. Some attempt will be made to consider these questions through a close reading of their work and a juxtaposition of the two very different texts, along with a brief revision of some of the main historical and generic aspects of women's travel writing in its development from the nineteenth to the twentieth century. This article aims to combine a discussion of the ethics of the choice of destination in a politicised world with a consideration of the discursive nature of representation always present in travel writing, by looking at a specific place and time, and focusing on travel writing written by women about this destination. To do so, we will refer to work by Said, Pratt, Buzard, Lisle, Fowler and Forsdick, Smith, Holland and Huggan, and others. 


\title{
2. Ethical perspectives on travel
}

A series of questions arises about these texts when we read them in the light of a geopolitical and ethical perspective which focuses on the inequality of wealth that lies behind much recent tourism. According to Carrigan (2011),

\begin{abstract}
[t]he effects of globalized mass tourism over the last half a century have been both striking and troubling. Many forms of post-World War II tourism exploit uneven distributions of wealth, remapping colonial travel patterns as increasing numbers of citizens from rich nations choose to visit much poorer states. Such rapid industry expansion has clear bearings on issues that are central to postcolonial studies in the era of corporate globalization.
\end{abstract}

(quoted in Fowler et al. 2014: 129)

The difference between travel writers and tourists has been questioned many times, for example by James Buzard (1993: 4), who has argued that from the perspective of the 'travelee' in a poor country like Spain, distinctions like 'antitourist', used sometimes to distinguish the sensitive traveller from the undiscerning tourist mass, are irrelevant. We have to ask why these relatively wealthy British women chose to come to Spain at that time, to what extent they were aware of the political situation in the country and whether they adopted a political or ethical stance towards the society they visited. Similarly, it is important to establish whether they ever felt uneasy about travelling in a country affected by war, poverty, division and dictatorship. Clearly the traveller who can choose their destination and itinerary freely, with a certain degree of economic ease and time to escape the daily routine, such as these women, is in a position of privilege. Their situation must be contrasted with that of the "travelees" (Pratt 1992: 78), those members of the local population who are subject to restrictions on travel or access to resources, as was the case with ordinary Spaniards after the war.

Debbie Lisle, in her book The Global Politics of Contemporary Travel Writing, discusses the issue of the ethics of travel writing with reference to discourse analysis and critical geography and historiography. She argues that „the travel writer - no matter what his/her background or ethnicity - identifies difference, places it in a value-laden hierarchy, and judges it accordingly." (Lisle 2006: 115). Travellers have a view of the place they travel to, and in fact it could be argued they not only have a view, they have a responsibility to be aware of the particular historical and social circumstances of our destination. The argument that we are only there as tourists is a thin one, when one chooses to visit a country that has recently undergone the trauma of a civil war, and is subsequently suffering the hardship inflicted by a dictatorship. Our idea of a place is already established before we set foot in the county. Our understanding 
of the world, of a particular place, of people, is affected by our reading of travel writing. This literary genre in turn is shaped by many discursive factors that go to make up the sense of reality we experience when we read someone's account of a journey in a foreign country. What we may perceive naïvely as an unmediated, objective description of a place is always and inevitably filtered through many levels of social, cultural and linguistic discourses of which the author may be unaware but which condition the image created in the text. The work of Edward Said is the basis for much of this debate about how discourse influences the way we construct our understanding of another culture:

\begin{abstract}
It hardly needs to be demonstrated again that language itself is a highly organized and encoded system, which employs many devices to express, indicate, exchange messages and information, represent, and so forth. In any instance of at least written language, there is no such thing as a delivered presence, but a re-presence, or a representation .... These representations rely on institutions, traditions, conventions, agreed-upon codes of understanding for their effects, not upon a distant and amorphous Orient.
\end{abstract}

(Said 1995: 22)

If in turn readers travel to the destination they have been reading descriptions of in travel texts, their own appreciation of the place is inevitably shaped by what has been written by earlier travellers. Thus, the reader's subjective experience is formed through discourse; the choice of sites and sights may be determined by the beaten tracks of earlier travellers, and contact with local people may be compared favourably or unfavourably with that of their predecessors. All of us, when we travel, are inevitably selective about what we see and what we remember, what we choose to photograph, the souvenirs we buy, the anecdotes we relate on our return or on our choice of postcards. We are never completely innocent travellers. Buzard has discussed this discursive shaping of travel since the development of the Grand Tour in the eighteenth century, through the growth of popular tourism and the rise of Cook's Tours, the development of the railways, and the importance of guide books, in the nineteenth and twentieth centuries. He argues that this history of travel is a gendered construction, as he considers "the gendered stereotypes of the post-Romantic paradigm, according to which 'travel' is achievable by lone males of demonstrably acute sensitivity, while 'tourism' appears a feminine endeavour requiring a constraining male solicitude" (Buzard 1993: 82). The lack of seriousness of the connotations of female 'tourism' compared with male 'travel' play a part in the style of the women travel writers discussed below.

In their introduction to Travel and Ethics: Theory and Practice (2014), the editors refer to the "creative potential of the encounter of travel writing" with other areas of humanities research such as gender studies, translation studies 
and ecocriticism, but point out there is still a long way to go on the question of the ethical aspect of travel:

\begin{abstract}
Although many of these approaches contain an implicitly ethical dimension and are often even motivated by a loosely ethical imperative to challenge dominant voices and explore alternative modes of intercultural contact and communication, the open, active, and enabling engagement of studies in travel writing with questions of ethics remains largely undeveloped despite the potential of such work to reinvigorate the field and expand the range of audiences with which it can speak.
\end{abstract}

(Fowler et al. 2014: 3)

Other writers have also debated the question of ethics and its relation to travel. Fowler et al. go on to discuss the question raised by Debbie Lisle in Global Politics, as to how we can judge the value of a travel text, as she claims an ethical approach to travel is increasingly important in our appreciation of the genre. Lisle has argued: "a travelogue can be judged as 'good' to the extent that it acknowledges, addresses and engages with its ethical and political responsibility to the other" (Lisle 2006: 265). Given this, Lisle is concerned about the absence of 'political reflexivity and critical thought' in most contemporary travel writing but nevertheless looks forward to more authors resisting the received codes of the genre and addressing the ethicopolitical dimension of cultural encounters (Fowler et al. 2014: 6).

\title{
3. Women travel writers and discursive voice
}

Women travel writers, despite being traditionally a minority compared with their male counterparts, have forged a voice in the field especially since the nineteenth century when their work began to be taken seriously both by the popular reading public and by the scientific establishment and literary critics. Shirley Foster has discussed the way women travellers in the Victorian period tended to assume the colonial voice which accepted the dominant textual constraints of the period to describe the foreign experience, such as "the use of a predominantly 'objective' style, careful documentation and the 'othering' of the foreign country by emphasizing details which will assign it an inferior or alien status" (Foster 1990: 18). There has been much debate as to the extent to which women travel writers identified with the colonial subject position or challenged that role and identified with colonized people, for example through their sympathy for oppressed peoples, given their own subordinate feminine role in their motherland. Foster argues that the traditional woman writer 
often represents foreigners sympathetically, as individuals with whom she tries to identify rather than as symbols of an alien 'otherness'. In her concern with relationships, rather than with larger political or social issues, she blurs the demarcation between 'them' and 'us' and may be less assertive than her male equivalent in her establishment of a subject position.

(Foster 1990: 24)

The tendency in the Victorian period was to overemphasize their femininity, substituting "self-effacement or self-mockery for more aggressive or positive self-assertiveness in order to demonstrate a true femininity [and] prove their modesty by claiming they never intended to expose their writing to the common gaze" (Foster 1990: 20). Alternatively women writers could adopt other strategies to validate their claim to speak with the voice of male authority:

\begin{abstract}
In order to authenticate their accounts and to guarantee the authenticity of their commentary they had frequently to take on a masculine voice, and at such points there is no discernible distinction between male and female writing ... They frequently appeal to earlier authorities, they include technical data often avowedly gleaned from male sources and consciously or unconsciously they base many of their interpretations on the assumption of their own personal and national superiority as white, British, middle class observers.
\end{abstract}

(Foster 1990:18)

Arguably, as the number of women travel writers published increased in the twentieth century, and as more women were able to travel due to their increased social independence, the rise of popular tourist routes and the general increase in wealth for large sections of society, the question of gender has become less acute in our reading of the genre. However, certain tendencies to think of travel writers as predominantly intrepid male explorers, while relegating women to the category of eccentric spinsters, sexual adventuresses or romantic wives accompanying their men, still tend to prevail in the twentieth century. For example, Unsuitable for Ladies (1994) and Wayward Women (1990) by Jane Robinson, or The Blessings of a Good Thick Skirt (1986) by Mary Russell.

More recently, Lisle distinguishes between colonial and cosmopolitan travellers, two groupings of travel writers that coexist at the end of the twentieth century and who are both determined by discursive constraints of the travel writing genre. The influence of postcolonial travel combined with an active feminist philosophy has meant that many women travel writers adopt a more cosmopolitan subject position, in an attempt to break down the cultural gaps and social hierarchy traditionally created between traveller and native. However, Lisle is suspicious as to the extent to which the apparently more progressive subject position of 'Cosmopolitan' traveller is really an advance on the colonial mindset. She argues: 


\begin{abstract}
the genre that offers the most opportunity to explore intersubjective positions between the self and the other is paralysed by literary conventions that protect the subject position of the travel writer ... this lack of reflexivity means that when new subjectivities - new 'special status' categories- emerged in travel writing they are soon assimilated into literary conventions that insist upon either a 'monarch-of-all-I-survey' subjectivity keen on reviving colonial and patriarchal visions, or a cosmopolitan subjectivity keen on encountering cultural difference only to overcome it in the name of universality.
\end{abstract}

(Lisle 2006: 133)

Lisle here is referring to the trope identified by Mary Louise Pratt, who describes two main types of travel writing with a corresponding narrative figure: the 'manners and customs' figure, which is impersonal with an absent narrator, and the 'sentimental' figure, which foregrounds the narrator. It is tempting to see these as reflecting male and female styles, respectively, but of course the situation is more complex than that. The 'monarch of all I survey' trope referred to above is described by Pratt as referring to a figure in an 'anticonquest' style of travel writing,

\begin{abstract}
By which I refer to the strategies of representation whereby European bourgeois subjects seek to secure their innocence in the same moment as they assert European hegemony. The term 'anti-conquest' was chosen because ... in travel and exploration writings these strategies of innocence are constituted in relation to older imperial rhetorics of conquest ... The main protagonist of the anti-conquest is a figure I sometimes call the 'seeing-man', an admittedly unfriendly label for the European male subject of European landscape discourse - he whose imperial eyes passively look out and possess.
\end{abstract}

(Pratt 1992: 7)

I would argue that despite Pratt's adscription of this Colonial category to male monarchs, it is really a discursive position that may be adopted by female as well as male authors if it suits their needs. Similarly, the Cosmopolitan subject position is perhaps more comfortable for many women writers, but is not exclusively female either: we are dealing with literary strategies based on linguistic tropes, not with biologically determined essentialist positions. The dilemmas involved in articulating an appropriate subject position in travel texts in relation to the locals described is clearly applicable to women writers in the twentieth century. Perhaps it is especially relevant for those women in the first part of the century who did not necessarily identify with the popular version of feminism which arose in the 1960s and which would tend to promote the importance of subjective experience over anything else.

So the question arises, what subject position, either colonial or cosmopolitan, did the authors considered here adopt in their writing about Spain? Clearly Spain was never a British colony, but in the period I am discussing it was not a 
popular destination for mass tourism either, and it had traditionally remained off the beaten track for the Grand Tour (which focused on France, Switzerland and Italy). Relatively few accounts exist from within the country until recently, especially compared with those of other countries as close to Britain. Esther Ortas Durand (2005: 57) has argued that the long history of wars and religious confrontation between Spain and Britain going back to the seventeenth century had left a legacy of ignorance, myth and superstition that clouded the information available to British travellers who might consider going to Spain. In terms of male travel writers to Spain in the nineteenth and early twentieth centuries: Richard Ford's famous account of travels in Spain in the nineteenth century, A Handbook for Travellers in Spain, published by John Murray in 1845 , is one of very few major accounts by a British traveller in Spain before the twentieth century. George Borrow published The Bible in Spain in 1841, describing his travels in Spain and Portugal between 1835 and 1839. Laurie Lee's account of walking across Spain from Galicia to Andalusia, described in As I Walked Out One Midsummer Morning, is based on his experiences in 1935, but was published in 1969. Gerald Brenan lived in Andalusia for many years from the 1920s, but his major works, The Spanish Labyrinth: An Account of the Social and Political Background of the Civil War (1943) and South From Granada: Seven Years in an Andalusian Village (1957) also came later. Other English speaking writers, such as Lord Byron, Washington Irving, Ernest Hemingway, George Orwell, Gordon West, Isabella Romer, Frances Elliot, Elizabeth Murray, Marianne North, Olivia Stone or Robert Graves, also had literary connections with Spain. Baedeker produced a guidebook to Spain and Portugal in 1901; Spain was gradually getting on the map for travellers, but was still largely unknown territory by the 1930s, certainly in comparison with France or Italy, for Britons.

On the question of a cosmopolitan subject position with respect to Spain, there is another problem for travellers, namely, how far they can identify with local people and relate to their concerns when these are so divided and interrupted by the special circumstances involved in the civil war and its aftermath. The normal difficulties of communicating with local people in a foreign language and across cultural division are exacerbated in an atmosphere of distrust and suspicion which extends both to neighbours and foreigners. Few Spaniards could speak English, and it is clear that the writers we consider here had varying degrees of struggles with Spanish or Catalan. It is unlikely we will ever hear the voice of ordinary Spanish 'travelees' encountered by the travel writers, but it is a fascinating imaginative act to consider what they thought of the northerners who passed through their villages or stayed a while in their cities.

Gender is inevitable in this debate, though it needs to be considered also in the light of social class and nationality. It is generally accepted in criticism of 
modern travel writing that gender plays a role in the discursive construction of a text. Carl Thompson, in his book Travel Writing, argues that the "need to demonstrate femininity on the page influenced both the topics women travel writer might discuss, and the style and tone she could adopt in discussing them" (Thompson 2012: 182). While he is referring here mainly to eighteenth and nineteenth century women travellers, I think this tendency continues into the twentieth century with a few special exceptions. The situation of many women in Spain in the first part of the century (except for the brief moment of the Republic, when they achieved enormous advances in equality and freedom) was much closer to that of many British women in the nineteenth century in terms of restrictions on their movements, education, ambitions, clothing and general visibility. Inevitably this meant that foreign women stood out in Spanish society simply by their ability to travel independently, to drive a car, to drink in bars and mix with men, or to work professionally. Each woman traveller has to decide to what extent they are going to fit in with local customs or accepted the consequences of defying them. Thompson discusses this briefly in reference to women travellers in the late twentieth century: "the cultures that they visit, equally, will sometimes require different conduct and costume from women" (Thompson 2012: 183). Having considered several theoretical aspects which serve to highlight the problems of dealing with travel writing as a simple reflection of an individual's journey at a particular time and place, we will now proceed to a reading of the works in question, and see how far they deal with the questions discussed above.

\section{Macaulay's Fabled Shore}

Rose Macaulay's account of her travels in Spain in 1949, Fabled Shore: From the Pyrenees to Portugal, is a travel text based on an individual's journey in the country (Macaulay was sixty six at the time), but which focuses almost entirely on historical and architectural information, provided objectively and in academic detail. This depth of description is given at the expense of almost any direct presentation of local people, reporting of conversations, or subjective thoughts on what is seen, beyond a repeated sense of loss. In fact, we can recognize clearly here the distinction described earlier by Mary Louise Pratt, between 'manners and customs' and 'sentimental' narrator figures: Macaulay definitely exemplify the former style. There is something of the 'monarch of all I survey' in her style, which retains a distance from the people travelled among in Spain, reflecting an impersonal style with an absent narrator: we learn nothing about the life of the author, how she chose the country, her personal opinions and so on. The important discursive element of their work is historical detail. The social and economic distinction is also increased by the fact that she travels by car at a time when few Spaniards owned cars, and very few women 
were ever seen driving. Sidonie Smith has pointed out the importance of the means of transport adopted by travellers and how it affects the relationships possible between traveller and 'travelee' during the journey:

New technologies of motion have also created new social relations over the last century. Consequently, they have affected the conditions, the rhythms, even the presentational styles of contact between the traveler and other travelers, between the traveler and strangers. They determine the specific dynamics of social encounters - their duration, their form, their potential effects, and their modes of communication ... Travelers in automobiles, unlike those in trains, can seek outof-the-way places and peoples on the obscure back roads.

(Smith 2001: 24)

There is a great difference between the distant contact Macaulay has with local people during her solitary drive through the almost empty roads of Spain, compared with the immediacy and familiarity of Chetwode's mode of transport, the horse. Spaniards see her as an outsider in terms of national customs, wealth, gender and purpose, and she spends little time in contact with them, simply due to the speed with which she can pass through their lives. Eleonora Federici, in her discussion of Macaulay's journey, focuses on the importance of the car in her experience of Spain:

\begin{abstract}
Macaulay's detailed account of places and people always starts from the roads she covers, roads that become sites of cultural exchange as much as her automobile becomes a site of cultural encounters. After sharing the intimacy of the car with local passengers asking for a lift the author's gaze changes ... In the intimacy of the car, a mechanical body that encloses its passengers, the author learns about Spanish culture form their voices and tales.
\end{abstract}

(Federici, 2006: 147)

Macaulay, an English writer with a love of classical studies, is intensely aware of the palimpsest of history that she encounters on her drive along the coast from Catalonia through Valencia, Murcia, Andalusia and on to Portugal. She describes in detail the different waves of cultural invaders who settled on the Mediterranean coast, for example this site near Alicante:

Here, it has been thought, was the original Greek Massilot Leuke Akra (one of Strabo's 'three small Massiliot cities' between the river Sucro and New Carthage), or if there was no Greek city, anyhow the Iberian town, then the Carthaginian, then the Roman Lucentum, destroyed and abandoned before the Moors built AlLekant, three kilometres west down the bay. But other archaeologists have believed the Tossal ruins to have been but an outlying stronghold of Alicante, which stood always where it now stands, Iberian, Greek, Carthaginian, Roman, Visigothic, Moorish, and now Iberian again. 
She is more interested in the ghosts of past peoples who occupied the land than in the present Spaniards and their current concerns: "You may wander through [Ampurias] among ghosts of Greek traders, Iberian vendors, Roman gentlemen lounging outside their villas or gossiping in loud Roman voices in the agora" (Macaulay 1986: 38). On the subject of time and travel writing, Lisle has argued

\begin{abstract}
... travel writers do not choose their destinations simply because the landscape is different, or because it is located on the other side of the world, they choose destinations that will allow them to go back in time as well as far away ... one can avoid the anxieties of a modern cosmopolitan global order by withdrawing into an imagined past where everyone knew their place within the hierarchies of Empire.
\end{abstract}

(Lisle 2006: 204)

This idea, of avoiding the anxieties of modern life, is an important one for several of the travel writers discussed here, and especially for the author of The Fabled Shore, where modern Spain is very much in the background of her thoughts compared with the wonders of the possibilities of mental time travel to its illustrious past. The text contains almost no direct contact with ordinary people, apart from occasional references to the Civil Guard who check her papers, and brief descriptions of soldiers or workers whom she picks up to give them a lift a few kilometres along the road. Children swarm around her car or follow her in the streets, and she is an object of much interest as a solitary woman driving her own vehicle:

\begin{abstract}
All over Spain, except in the more sophisticated cities, my driving by was greeted with the same cry - a long, shrill cat-call, reminiscent of a pig having its throat cut, usually wordless, but sometimes accompanied by 'Olé, Olé! Una señora que conduce!' For Spanish women do not drive cars. I was told this many times, and indeed, observation confirmed it; I saw not a single woman driving all the time I was in Spain.
\end{abstract}

(Macaulay 1986: 41)

However this is just a background distraction to her; her real interest lies in discovering the exact location of a lost Greek town, describing the architecture of a ruined church, or swimming in the sea in tiny empty fishing villages such as Torremolinos.

According to Federici (2006: 148), "Macaulay is not an elitist traveller. Her travel is commissioned and financed by her publisher so that she can write a book on the countries [Spain and Portugal] she is visiting. It is not a luxurious holiday, she even sleeps in the open air". But to most of the Spaniards she passes on her trip, this journey would be the height of luxury: freedom of movement and the ownership of a car were in fact the privilege of the élite in Francoist Spain. We are not given any personal reason as to why Macaulay is undertaking this journey 
in August, nor why she has to hurry towards the end of the trip; she makes no comment on the fact that the country is ruled by a dictatorship, nor what she thinks about the Civil War. Inevitably there are some references to this conflict, especially in terms of churches that have been destroyed: "The flames consumed nearly everything; what they left was looted or destroyed. Mysterious madness which ever and anon attacks the Spanish, driving them to these strange pyrrhic frenzies!" (Macaulay 1986: 32) but it is quite remarkable how little Macaulay enters into the life of 1940s Spain, keeping her eyes strictly fixed on the past. However she does offer a dense, knowledgeable and highly descriptive account of the cultural traces and archaeological footprints of Spain's complex, rich history. Macaulay does not offer any insight into her own personal feelings towards Franco's Spain, and nor does she attempt to portray the feelings of Spanish people, apart from a very few exceptions.

As Said pointed out above, all discourse is influenced by what has already been written and read, and this in turn affects how we perceive the Other. Macaulay describes the various books she loads into her car before setting out for Catalonia, and these books are an important part of the way she approaches each new place. ${ }^{1}$ She comments, "one is following in the tracks of innumerable other tourists, whose comments, whose tastes and distastes, whose experiences and points of view, cannot fail to excite surprise" (Macaulay 1986: 16). Despite this discursive focus on history and architecture, Macaulay is aware she is travelling barely eleven years after the end of the war but deals with the subject as a secondary issue on her agenda. She meets a sacristan who "was still full of the civil war; the English radio and papers, said he, had not understood it, had got the facts wrong. Actually there had been many Russians fighting for the Republicans, and very few - but pocos, pocos - Germans and Italians on the nationalist side" (Macaulay 1986: 82). This free indirect style gives us the gist of a conversation but avoids her response. Shortly after this encounter, she arrives in Barcelona and generalizes: "Even those who grumble, who hate the regime, the poverty, the lack of liberty, the fettering of Catalonia to Castile, the sense of defeat, as it is obvious very many of them do, will on a day of merrymaking make merry" (Macaulay 1986: 83). This is one of the few moments when she refers directly to the feelings of the local people, yet she does not say how it was 'obvious' that people felt this way about life in post-war Spain. It is not clear how much Spanish or Catalan she can speak or understand: in Valencia she comments "the Valencians were no easier to understand, except when they condescended to speak Castilian, than the Catalonians; this was disappointing" (Macaulay 1986: 105), nor are we given examples of contact with people that could have led to serious discussions about their attitudes or

$1 \quad$ See Macaulay (1986: 17) for her list. 
political grievances. Poverty is always easy to identify, but there is no attempt to find out whether people were poorer than in the past, or how they felt about it, or whether her own relative wealth bothered her.

Other comments about the people she encounters at inns, for example, are vague generalizations and descriptions of people as 'kind' and 'charming': "There is an obliging kindness and courtesy about the Spanish, when they see occasion for it, that exceeds, I think, any other" (Macaulay 1986: 103), without any more personal connection with individuals. The war seems to be viewed as a chronic, intrinsic aspect of Spanish life, as when she describes her arrival in Valencia city: "Ancient and modern civilizations, ancient and modern savageries, always so closely intertwined in Spain" (Macaulay 1986: 114). Another reference to modern reality comes in Denia at an inn where local people dine late, with their children, in a very un-English manner, and Macaulay comments on hunger: "Spanish children are not over-fed; Spaniards seldom are this, and at present, many of them are pretty hungry" (Macaulay 1986: 133). On one rare occasion she is shown around by a man who "had fought against Franco, and had spent some time in prison. He said that most Spaniards wanted Franco to go; he himself (polite man) would prefer a democracy on the English plan" (Macaulay 1986: 135). Again, Macaulay makes no comment on her reply or on what she thought of the issues raised by this conversation. Whether this was a kind of mental censorship designed to avoid problems during her trip, or whether she was simply not very interested in modern Spain given her enthusiasm for the past, is not clear.

Once again the question of the ongoing post-war conflict arises when the author is advised not to travel after dark between Guadix and Granada, as the roads "were infested by a predatory maquis, who held up travellers and cars by night, to show their disapproval of the present government" (Macaulay 1986: 152). Rather than go into depth as to why and how these outlaws survive in the hills of the Sierra Nevada, Macaulay relates them to historical traditions of bandits, with no political significance:

\footnotetext{
These were the mountains of the Granada maquis against whom I had been warned; the descendants, I suppose, of the ancient banditti, Iberian, Saracen and Christian, who had always haunted this sinister country. But I met no maquis; or if maquis they were, these occasional goat-herds and donkey riders, they wore an innocent and friendly air.
}

(Macaulay 1986: 159)

This is partly a debunking of a typical tourist myth about Spain - the dangers of bandits in the hills - but it also trivializes the problem of what happened to those on the losing side in the war and essentializes them as timeless characters that have always existed in the Spanish landscape. 
Her style distances itself from the present through the discourse of history, and enables the writer to travel through Spain and make generalizations about its people without getting close to any of them or reflecting their individuality on anything but a superficial level. This benefits the focus on an outsider's, detached view of a culture, as we are not diverted from the profoundly detailed levels of information which the author wishes to impart. However, it sidesteps the moral or ethical questions raised by the present paper as to the responsibility on the part of a travel writer to engage with the culture in which she is (temporarily) living, to take time to meet individuals and find out what they think and feel, and reflect this in their work. Innocent and friendly goat herds and donkey riders also have a recent tormented history, a personal story to tell, and a role in society, however humble. The next travel writer we will consider managed to get a lot closer to the people she travelled along and reflects this connection in her work.

\section{Chetwode's Two Middle-Aged Ladies in Andalusia}

Penelope Chetwode travelled to Spain in 1961, and between November and December of that year, spent a month on horseback exploring the interior of Andalusia, far from the coast and the burgeoning tourist areas. Her account of this trip was published in 1963 as Two Middle-Aged Ladies in Andalusia by John Murray. The Englishwoman was 51 at the time of the trip, and her mare was of a comparable age: hence the ironic title of a work that gives a unique insight into country life in Spain during the Franco dictatorship. The Civil War is not a big issue for Chetwode, who admits to knowing little of the conflict: "As I was producing and rearing my son during the civil war, 1936-39, my ignorance of its origins is profound ... so that I can only judge a small corner of Spain as I see it today" (Chetwode 2002: 86). Chetwode had no qualms about the morality of going to a country ruled by a dictatorship; initially her resistance to friends who encouraged her to visit Spain was based on not knowing the language or culture, and already having her interests filled by Italy and India. She decided to go because she was a huge horse-lover, and was attracted by the idea of undertaking a conducted riding tour in order to prepare herself for independent travel in the region by horse. She was also an ardent practising Catholic, converted from Anglicanism (which led to many problems in the relationship with her husband, the British Poet Laureate, Sir John Betjeman), and found many aspects of Spanish culture easy to adapt to and very satisfying on an aesthetic, religious and philosophical level. In many ways, like Macaulay, Chetwode is attracted to Spain by the desire to "avoid the anxieties of a modern cosmopolitan global order" quoted above, as she seems to find little to admire in 1960s Britain, compared with her delight in the simplicities and often 'medieval' traditions of rural Spain. 
The interest of her text, apart from its humour and understated style, lies in her ability to portray a society which seems to have changed little from medieval times and present this as a kind of paradise, despite many of the practical problems she encounters. She also succeeds in demonstrating the falsity of many British prejudices towards Spanish culture, such as the idea that Spaniards are cruel to animals, that Andalusia is rife with bandits, or that a backwards-looking lifestyle in terms of material possessions necessarily means cultural impoverishment. Chetwode also challenges the images of Spain she finds in some classic English texts by travellers in the nineteenth century (like Macaulay, she is influenced by her reading) such as George Borrow in The Bible in Spain (1843), who accuses Andalusian men of being "vain and foolish", and which she denies (Chetwode 2002: 4) based on her experience with the man who runs the riding holiday. Literary traditions are very important to her experience of Spain, and she refers often to Richard Ford, Gerald Brenan, Cervantes and other travellers and writers about the country. Like all British travellers to poorer countries, she is pleased by the advantages of the exchange rates at the time, and points out that she chooses to stay off the beaten track in basic inns (posadas and fondas, where she can stable her horse) while "there are excellent hotels in all the great sightseeing centres and coastal resorts of modern Spain ... you can stay in a first-class hotel for the same en pension rates as in a third-class hotel in Italy" (Chetwode 2002: 6). What she means by a typical posada is "an inn with stables attached, the animals being often better housed and fed than the human beings. Both enter by the same front door, which in the smaller posadas leads directly into the living room" (Chetwode 2002: 8). The fonda is described as inferior to the posada due to the all-important question of the toilets; the posada "possesses only stable sanitation. When the water variety is attempted [in fondas] it is always a dismal failure ... The Spaniards possess a great variety of talents but plumbing is not one of them" (Chetwode 2002: 9). By "stable sanitation" Chetwode refers to the fact that the family and guests of the inn have to retire to the straw on the stable floors for calls of nature, and follow the protocol:

\footnotetext{
The technique of using stable sanitation successfully and without undue strain on the nerves is as follows: when you want to enter the stable to attend to your horse, you open the door with a smile on your face, switch on the light and advance towards the animal, welcoming any help from your landlord or fellow-guest which may be offered. When, however, you wish to enter it for the other purpose you go towards the door with a look of grim determination upon your face, do not turn on the light, and slam the door hard behind you. Should you hear a giant peeing close by it is almost certain to be a mule or donkey: and when your eyes, growing used to the dim light, discern the figure of your landlady squatting in a corner, the custom is for both of you to roar with laughter as if this clandestine meeting were the most natural thing in the world, which indeed it is.
}

(Chetwode 2002: 9) 
This example of the style and the experience of the traveller indicates both the simplicity of the world she has entered, and the positive attitude with which she adapts to its customs. (It is probably significant that Chetwode grew up in India, the daughter of the Commander-in-Chief of the British army there, Field Marshal Philip Chetwode, First Baron Chetwode. She was used to long, tough rides in wild country with basic facilities from an early age). Another aspect of local life to which she adapts quickly and without complaint is the food:

\begin{abstract}
The staple diet of rural Andalusia consists of vegetable soups and stews ... Sometimes the beans are replaced by rice, and now and then there will be the added thrill of lumps of fat pork. When eating these cocidos and pucheros day after day, week after week, the lack of relish is compensated for by the knowledge of how wholesome they are .... Apart from the products of the pig, meat is rarely met with outside the tourist areas.
\end{abstract}

(Chetwode 2002: 10)

She makes it clear she is not a typical tourist: "To sum up, posada life must be entered into in a spirit of adventure. The lack of modern comforts and gastronomic pleasure, which the average tourist demands, will soon be forgiven and forgotten if you decide to become a posada specialist" (Chetwode 2002: 2). Most of the houses and inns she stays in lack glass in the windows, with the consequent cold, and food is eaten communally from a large pot and wine drunk from a common leather flask, each diner providing their own knife and spoon, as forks, plates and glasses are not used; one man describes how he had heard that in Madrid "at the hotels each person used several knives and forks and spoons and plates and glasses at every meal. Did I think this was really true? And what was the point of it? ... The custom in Tiscar, I assured him, was far more sensible and friendly, as well as saving the women a lot of work" (Chetwode 2002: 7). Chetwode has no interest in flaunting her superior social experience or undervaluing the simple logic of local life; she always does her best to see life from the local perspective and try to understand why things are done in this way.

So, once she has adapted to the basic conditions of rural life in Andalusia in the early 1960s, what does Chetwode make of the level of satisfaction of people after 22 years of Franco's regime? On the whole, she finds little to criticise. The people she encounters on her ride through tiny hamlets and poor villages are unfailingly generous, helpful and courteous, despite the fact that in many places, they have never met an Englishwoman before. She is invited into houses by complete strangers: "I caught up with three men, one of whom asked me home for the night, saying he had a wife and five grown-up children but that there would be room for me too ... He seemed very contented with his lot" (Chetwode 2002: 23). One of the few references to the after-effects of the war occurs on this occasion: "I gathered that there used to be bandits in the 
surrounding hills who would come in and demand half the food and money in the house. They were a great nuisance and were mostly men from the losing side in the war, but they were finally cleared out in 1955" (Chetwode 2002: 24). We are not told what this "clearing out" consisted of, nor is there any reflection on what life was like for those on the losing side since 1939, in the same way that Macaulay also dealt with the maquis/bandits. Another reference comes in a conversation with the parish priest, Don Antonio, who says:

\begin{abstract}
The British had said some unkind things about Spain: that we did not understand that Franco's rule was quite different from that of Mussolini or Hitler; that before the civil war communist infiltration was rife; that Franco had saved the country and preserved the Catholic Faith [...] and that the people were poor but happy, and that everyone had enough to eat.
\end{abstract}

(Chetwode 2002: 85)

Chetwode comments, after this orthodox defence of the regime, on her ignorance of the civil war and describes how she had lived in fascist Rome for six months and in Berlin for three months in 1933, saying "I can only agree with Don Antonio that the present regime in Spain has created a different atmosphere to that in the hundred per cent fascist countries of Italy and Germany before World War II" (Chetwode 2002: 86). She does not enter into any discussion of exactly in what way the fascism of those countries differs from what is presumed to be a lesser degree in Spain. In terms of contact with the authorities, she is stopped several times by the Civil Guard, who check her papers, and in particular, those of her horse, and who are pleased to find her Missal among her books, proving her status as a good Catholic (Chetwode 2002: 39). Religion is the source of several brief references to the conflict, when she describes various churches which were destroyed during the war. Another priest

spoke seriously about Franco and said he was un santo and that he never took a
big decision without spending the night in prayer before the blessed Sacrament;
that Señora Franco once came to Ubeda for Holy Week but that her husband
couldn't come as he always spent it in retreat. He went on to tell me that the civil
war had been like the Roman persecution in early Christian times: that he had
only escaped with his life because he ran ... a school for poor boys. He hid three
Carmelite friars in his house for some time and knew of two others who died as
the result of being tortured. He then showed me round the church, pointing out the
damage that the Reds had done.

(Chetwode 2002: 118)

Again, these accounts rendered in free indirect speech are recorded without comment; we do not hear the voice of those on the losing side, perhaps because those who survived hide their views, or perhaps because Chetwode chooses the company of priests and religious activists for personal reasons. 
The line between tourism and hospitality is often blurred, and she is treated as a special guest who is honoured: she is given the best bedroom in several houses she stays in, while "mother and father slept on the floor in front of the fire (Chetwode 2002: 21). Elsewhere a rabbit is killed in the kitchen in preparation for a special meal in her honour: "I had witnessed a sacrifice on the hearth, a sacrifice that was being offered for me as the guest of honour" (Chetwode 2002: 115). She soon feels part of the family wherever she stays, even at inns: "Having quickly become part of the Diez family in the way one does in Spain, I now had my meals with them at their cosy-table instead of in the cold comedor" (Chetwode 2002: 96). Her novelty factor is illustrated in a scene at breakfast in an inn, when she is observed, as always, by troops of children; one boy climbs up to look through the shutters:

\begin{abstract}
The boy would push them open again and shout to the inquisitive crowds below him: 'The woman eats! The woman reads! The woman writes! ... Sometimes I got up, waved my arms and screamed 'Go away!' when my persecutor would disappear for a split second only to pop up again like a jack-in-a-box: 'The woman speaks!'
\end{abstract}

(Chetwode 2002: 41)

Chetwode describes in more detail the children she meets in a troglodyte colony, where again she dispels some of the myths of cave dwellers held by the English:

\begin{abstract}
I would like above all to make it clear that the world 'cave' is not synonymous with 'slum' ... The trog children are clean and well-dressed in brightly coloured hand-knitted jerseys and home-made skirts and trousers. They cannot afford the luxury of expensive shoes but wear rope-soled canvas ones or sandals. I saw no signs of rickety legs and they have lovely skins and beautiful teeth. Their every gastronomic whim is not catered for and no irritating ice-cream van drives past their caves ... and they have no pocket money with which to buy sweets. But theirs is not the starvation-level poverty of the east ... they doubtless have tougher bodies and better teeth than a lot of over-indulged children in our welfare state.
\end{abstract}

(Chetwode 2002: 46)

Other aspects of life praised by Chetwode include the national health service ("... nobody need have any fears about the state of medicine or dentistry in modern Spain which is as up-to-date as in England with the same drugs in constant use" Chetwode 2002: 121), the religious education of children and the general education of the young: "Most of [the younger] generation in the south of Spain can read and write, education having made much progress under the present regime: it is the grandmothers who are largely illiterate" (Chetwode 2002: 78). She also respects the communal effort put in during the matanza to prepare the food from the recently killed pig, when the women work through the night 
(Chetwode 2002: 72). She admires the local earthenware bowls and amphorae used for cooking and storing water, and curses modern innovations, some plastic kitchen items received as wedding presents: "Blast and damn all plastic consumer goods seeping in to spoil the virgin beauty of Tiscar" (Chetwode 2002: 79): their owner shows them "with pride", but progress is very much seen as a doubtful virtue by the outsider: "I love the cosas de España and cannot bear to think of them changing" (Chetwode 2002: 98). She is very much anti-car, and values Spain for its maintenance of work animals: "It is wonderful to go thus backwards in time to the life of a hundred years ago when both one's transport and one's fun depends on the horse and not on the internal combustion engine" (Chetwode 2002: 101); elsewhere she writes "I had got right back into the world of George Borrow and Richard Ford, for apart from the wireless and the naked 15-watt electric light bulb, rural Spain still remains exactly as they describe her" [in the nineteenth century] (Chetwode 2002: 139). The attraction for the unspoilt preindustrial world is clear; however, she does not question whether the local people are equally happy to live in the past, in comparison with the rest of western Europe, or whether Spain would be happier 'catching up' in terms of material wealth. The problem with this attitude is that it is easy for a short-term traveller to pass through an area that they see nostalgically as idyllic, and assume that this way of life beats late twentieth century consumerism, but of course they have their (air) ticket home and can have the best of both worlds when it suits them to return to the comforts of modern life. Patrick Holland and Graham Huggan highlight this tendency, which they refer to as "imperialist nostalgia", citing the anthropologist Renato Rosaldo (1993) who argues, "In any of its versions, imperialist nostalgia uses a pose of 'innocent yearning' both to capture people's imaginations and to conceal its complicity with often brutal domination (Rosaldo 1993: 70; quoted in Holland \& Huggan 2000: 29). They relate the concept to travel writing, and it is applicable to Chetwode's discursive style, as they make clear there is no need for an actual imperial relationship to exist:

Imperialist nostalgia comes in handy for contemporary travel writers, who can
deploy it to mystify their own economic motives, as well as to yearn for the
'simpler' ways of life - often rural, premodern, preindustrial - that they, and their
metropolitan readers, persuade themselves they need. Imperialist nostalgia, as
Rosaldo sees it, does not have to depend on a vision of Empire; it describes a
more generalized, pastoral mode of wistful reminiscence that seeks control over,
but not responsibility for, a mythicized version of the past.

(Holland \& Huggan 2000: 29)

A key passage sums up Chetwode's attitude to the problem of how to evaluate poverty in material terms and reconcile it with cultural wealth, and how complex this question is; once again she discusses the life of the children she has met: 
I wish I could convey something of the simplicity of these Andalusian village children: they possess no toys bar those provided by a pig's inside; they eat the plainest of food and have no outings to the seaside in luxury motor-coaches; they have never been to a cinema nor watched television; they live in a non-atomic age knowing nothing of the world beyond the two pueblos on either side of them ... And yet even the older ones appear to enjoy a sense of fun and wonder which it is increasingly difficult to find in a land of plenty where God is the Internal Combustion Engine and children's teeth are ruined at an early age by a surfeit of sweets. What is the answer? How can one preserve a balance between poverty and plenty so that true happiness is not corrupted by a false sense of values? Of course I do not know. If I did I should have solved the riddle of the Universe.

(Chetwode 2002: 80)

All in all, the final evaluation Chetwode makes of her experience in Spain is overwhelmingly positive. She feels she has seen "people as God made them to be .... I had enjoyed only the most friendly and unselfish traits in their characters which, added to the extraordinary beauty of their countryside, made me feel that I had ridden through the garden of Paradise before the Fall" (Chetwode 2002: 148). However, we must offset this pre-lapsarian idyll with another image from the text, when she shares the Sunday lunch of a family living in the troglodyte village, which consists of "a thick pancake made without eggs or milk but simply with flour, water and olive oil beaten together and fried over the open fire ... I could not help thinking of all the roast Sunday joints on the tables of England" (Chetwode 2002: 54). Her hunger not satisfied, Chetwode returns to her inn to eat the chicken that was killed for her: a reminder that she remained a privileged tourist, lucky enough to be able to buy extra protein when she felt like it, and not really a member of an Andalusian family after all.

\section{Conclusion}

In conclusion, the texts considered here show a contrast in terms of discursive styles and narrative positions in two travel books about Spain during the Franco years. If we return to the initial question posed by Lisle, how can we assess these works? Lisle suggests we could evaluate travel writing as 'good' if it "acknowledges, addresses and engages with its ethical and political responsibility to the other" and looked for examples of the genre which show "political reflexivity and critical thought" (Lisle 2006: 256). The works we have analysed vary greatly in terms of how the narrator deals with these questions of ethical and political responsibility. We find the 'manners and customs' tendency described by Pratt, offering an impersonal style with an absent narrator who focuses on objective facts and figures presented from a detached position of allseeing omniscience: here we can identify, to a large extent, Rose Macaulay's 
Fabled Shore as what is important is the past, history and its cultural traces, not modern Spanish life and the ethical questions it provokes. Similarly her choice of the car as a means of transport separate her from the local culture both in terms of speed of movement and isolation from local people, as well as exemplifying her superiority in terms of wealth and gendered privilege. To this extent we can identify her as a 'colonial' traveller, who uses the techniques described by Shirley Foster to give herself male status in the field by relying on the objective, factual style of travel writing in contrast to the subjective, introspective style generally identified with women writers.

In contrast Penelope Chetwode's Two Middle-Aged Ladies in Andalusia offers a close-up of people in southern Spain experiencing the ordinary details of daily life under the dictatorship. Chetwode brings to life many aspects of reality which are important to local people, and her choice of a horse as her means of transport is a simple and effective way of travelling where cars cannot go, where tourists have never been, thus enabling her to mix in with the background in a way that Macaulay, standing out as a woman driving an expensive car, could never do. On the other hand, the author's sense of identification with the religious traditions and the lack of materialism she encounters mean she avoids engaging with the implicit political questions that underlie the apparent paradise she experiences. She is also, in Lisle's terminology, a 'cosmopolitan' as opposed to a 'colonial' traveller, as she allies herself subjectively with the local people, and avoids the temptation to see them as the 'other'.

Both books demonstrate the importance of discursive literary and social influences on the individual writer and traveller, in terms of the influence of other literary works and the expectations they create about the society to be visited, as well as the tendency of the writer to focus on what is seen as interesting to the home readership, rather than any sense of responsibility to the people among whom she travelled. But at the same time, the juxtaposition of these two works reminds us that the individual traveller takes with them their own agenda, interests and style of travelling, and that this individuality is what has most impact on the way they interact with the locals, and thus on the content and themes of the work finally published. The lacunae that a modern reader may sense in these texts in terms of political and ethical engagement may simply be due to the fact that the writers in question were more interested in their own personal quests for escape from northern reality, than to an active decision to avoid complex local issues. In the case of Macaulay, the focus is on escaping the present through an imaginative reconstruction of historical Spain, while for Chetwode, the present is similarly evaded, but through a celebration of the simplicity of peasant life in a pre-industrial paradise. Neither author, in the end, wants to look too closely beneath the surface to question the reality of post-war Spain. 


\section{REFERENCES}

\section{PRIMARY SOURCES}

Chetwode, Penelope. [1963] 2002. Two middle-aged ladies in Andalusia. London: John Murray Travel Classics.

Macaulay, Rose. [1949] 1986. Fabled shore: From the Pyrenees to Portugal. Oxford: Oxford University Press.

\section{SECONDARY SOURCES}

Borrow, George. 1841. The Bible in Spain. London: John Murray.

Brenan, Gerald. 1943. The Spanish labyrinth: An account of the social and political background of the Civil War. Cambridge: Cambridge University Press.

Brenan, Gerald. 1957. South from Granada: Seven years in an Andalusian village. London: Hamish Hamilton.

Buzard, James. 1993. The beaten track: European tourism, literature and the ways to "culture" 1800-1918. Oxford: Oxford University Press.

Carrigan, Anthony. 2011. Post-Colonial tourism: Literature, culture and environment. London: Routledge.

Federici, Eleonora. 2006. Rose Macaulay's Fabled shore: Driving through cities and landscapes. In Maurizio Ascari \& Adriana Corrado (eds.), Sites of exchange: European crossroads and faultines, 41-51. Amsterdam \& New York: Rodopi.

Ford, Richard. 1845. A handbook for travellers in Spain. London: John Murray.

Fowler, Corinne, Charles Forsdick \& Ludmilla Kostova (eds.). 2014. Travel and ethics: Theory and practice. Abingdon: Routledge Taylor and Francis.

Foster, Shirley. 1990. Across new worlds: Nineteenth century women travellers and their writings. Hemel Hempstead: Harvester Wheatsheaf.

Holland, Patrick \& Graham Huggan. 2000. Tourists with typewriters: Critical reflections on contemporary travel writing. Ann Arbor: The University of Michigan Press.

Lee, Laurie. 1969. As I walked out one midsummer morning. London: Andre Deutsch.

Lisle, Debbie. 2006. The global politics of contemporary travel writing. Cambridge: Cambridge University Press.

Ortas Durand, Esther. 2005. La España de los viajeros (1755-1846): Imágenes reales, literaturizadas, soñadas [The Spain of the travellers (1755-1846): Real, fictional and dreamed images]. In Leonardo Romero Tobar \& Patricia Alargeui Elduayen (eds.), Los libros de viaje: realidad vivida y género literario [Travel books: Lived reality and literary genre], 48-89. Madrid: Universidad Internacional de Andalucia (Ediciones Akal).

Pratt, Mary Louise. 1992. Imperial eyes: Travel writing and transculturation. London: Routledge. Robinson, Jane. 1990. Wayward women. Oxford: Oxford University Press.

Robinson, Jane. 1994. Unsuitable for ladies. Oxford: Oxford University Press.

Rosaldo, Renato. 1993. Culture and truth: The remaking of social analysis. London: Routledge.

Russell, Mary. 1986. The blessings of a good thick skirt. London: Flamingo. 
Said, Edward. [1978] 1995. Orientalism. London: Penguin.

Smith, Sidonie. 2001. Moving lives: Twentieth century women's travel writing. Minneapolis: University of Minnesota Press.

Thompson, Carl. 2012. Travel writing. (The New Critical Idiom.) London: Routledge. 